Peter B. Best ${ }^{\dagger}$, Dmitri Tormosov, Anabela Brandão* and Yuri Mikhalev

\title{
Geographical variation in the body size of adult female sperm whales (Physeter macrocephalus) - an example of McNab's resource rule?
}

DOI 10.1515/mammalia-2015-0042

Received March 11, 2015; accepted January 14, 2016

Abstract: This study investigates possible regional variations in size composition of adult female sperm whales (Physeter macrocephalus) using data from 3302 pregnant individuals taken on Soviet whaling expeditions to the Southern Hemisphere 1961/62-1974/75. A general linear model (GLM) was used to take the covariates of expedition, latitude and ocean basin into account. The average body size decreased from south to north in each ocean basin, with the biggest decrease (about $200 \mathrm{~cm}$ ) in the Indian Ocean; followed by the Pacific Ocean (about $110 \mathrm{~cm}$ ), and the Atlantic Ocean (about $80 \mathrm{~cm}$ ). Independent data confirm the small size of female/immature sperm whales in some tropical areas of the Indian and Pacific Oceans. The mechanism responsible for this geographic variation in sperm whale growth could reflect culturally transmitted differences in foraging behaviour between clans of female/immature sperm whales in response to differing availabilities of prey resources by geographical region McNab's resource rule. However there is little available information for such a mechanism to be readily identifiable. Although data for oceanic squids (sperm whale's main source of food) are lacking, there is evidence that the individual sizes of neritic species are positively correlated with latitude. Hence feeding in equatorial regions may be energetically more demanding due to smaller individual prey size, with consequent effects on growth rate.

†Peter Best passed away in April 2015. He was an outstanding scientist and a great colleague who is sadly missed

*Corresponding author: Anabela Brandão, Marine Resource Assessment and Management Group (MARAM), Department of Mathematics and Applied Mathematics, University of Cape Town, Rondebosch, 7701 South Africa, e-mail: anabela.brandao@uct.ac.za Peter B. Best: Mammal Research Institute, University of Pretoria, C/o Iziko South African Museum, P.O. Box 61, Cape Town, 8000 South Africa

Dmitri Tormosov: Str. Karl Marx, apt. \#5, house \#76, Kaliningrad, 236022, Russia

Yuri Mikhalev: Solnechnaya St. 10, apt. 45, Odessa, 65009 Ukraine
Keywords: adult female; body size; growth; latitudinal gradient; population difference; resource rule; sperm whale.

\section{Introduction}

The sperm whale (Physeter macrocephalus; Linnaeus, 1758) is a pelagic, deep-sea species of cetacean with seemingly few geographical barriers to movement, especially in the Southern Hemisphere. Mature males migrate seasonally between high latitudes and warmer waters, while in the Southern Hemisphere females and juvenile males are widely distributed in waters north of the subtropical convergence. Both sexes can range widely, with maximum shortest-distance movements of $7400 \mathrm{~km}$ for males and $4332 \mathrm{~km}$ for females recorded, including some involving trans-oceanic or trans-equatorial passages (Ivashin 1967, Mizroch and Rice 2013).

Genetic studies have found low but significant levels of differentiation between ocean basins using mtDNA (Lyrholm and Gyllensten 1998), but either no significant (Lyrholm et al. 1999) or a low but significant differentiation using microsatellites (Bond 1999). This possibly indicates more frequent inter-oceanic movement in males than females (Lyrholm et al. 1999). Non-genetic differences have also been found in social structure between female sperm whales from the Eastern Pacific and North Atlantic Oceans, with grouping of family units and the formation of sympatric cultural clans occurring in the former but not in the latter (Whitehead et al. 2012).

Within ocean basins, mtDNA evidence of genetic differentiation is less common (Lyrholm and Gyllensten 1998, Lyrholm et al. 1999), but has been found between femaledominated samples from either side of the North Atlantic (the Mediterranean and Gulf of Mexico; Engelhaupt et al. 2009), while in the North Pacific a study using microsatellites, mtDNA and single-nucleotide polymorphisms revealed low-level but significant differentiation between whales in the California Current and those off Hawaii and in the Eastern Tropical Pacific (Mesnick et al. 2011). 
Vocal clans of groups of females and immature offspring that share a repertoire of distinctive culturally determined vocalizations, have been found to be largely sympatric within the South Pacific Ocean (Rendell and Whitehead 2003), whilst sympatric cultural clans were not found in the North Atlantic (Whitehead et al. 2012) and vocal clans off the coast of Japan and the Ogasawara Islands in the northwest Pacific were found to be geographically separate (Amano et al. 2014). While there is no simple relationship between vocal dialects and maternal genetics, a comparison of mtDNA variation among vocal clans in the South Pacific indicated that vocal membership explains a larger amount of genetic variation than geographical location (Rendell et al. 2012).

No studies to date have revealed significant geographical variation in morphometrics or other phenotypical characters in the sperm whale, which is otherwise regarded as a monotypic species (Rice 1989, Mizroch and Rice 2013). In this article we examine the sizes of pregnant female sperm whales taken in pelagic whaling (mainly in the Southern Hemisphere) for possible evidence of geographical differences in growth, and suggest that the observed trends are consistent with the "resource rule" of McNab (2010), where mammalian species become larger or smaller depending on the size, abundance and availability of resources.

\section{Materials and methods}

From 1948 to 1949, Soviet whaling expeditions operated widely in the Southern Hemisphere and with little adherence to international restrictions. Practically all whales available in an area were taken (Mikhalev 2000) including those that were under the legal length, lactating or calves: the idea was to leave a "barren desert" (Golovlev 2000). Although many of these catches were not reported or were falsified in official statistics at the time, subsequently many of the true figures have come to light (Anonymous 1995, Yablokov and Zemsky 2000, Ivashchenko et al. 2011, 2014). These include 22,329 sperm whales additional to the official statistics. Because of the widespread and virtually non-selective nature of this hunt, these catch data potentially provide an unusually representative sample of the sperm whale population, surpassed in coverage only by the nineteenth century open-boat fishery, but (unlike those data) including details of sex, length and reproductive condition of all the whales taken. To reduce the effects of differing age compositions of the catch, only data from pregnant individuals as a proxy for adult females have been used here.
Information on a total of 2132 pregnant females was available from sperm whales processed aboard the Soviet factory ship Yuriy Dolgorukiy during the Antarctic seasons 1961/62-1974/75. Available data included the date of capture, position of capture (in degrees, minutes and decimals of a minute), length of the foetus (to the nearest $\mathrm{cm}$ ) and sex. Three obvious outliers were detected and deleted from the database. These were females 18.9-21.4 m long, caught between $50^{\circ}$ and $63^{\circ} \mathrm{S}$, and thus very unlikely to be sperm whales - all were taken in the 1961/62 season. A more serious issue surrounded those foetuses for which the length was recorded as $1 \mathrm{~cm}$, of which there were 104 (or $4.9 \%$ of the total). If the embryo was lost, the length was also recorded as " $1 \mathrm{~cm}$ ", so at first sight it is not clear which of these 104 records refer to foetuses of $1 \mathrm{~cm}$ and which to lost foetuses. Where possible, the original whale "passports" (individual catch records initiated by catcher crew and completed by scientists on the factory ship - Ivashchenko et al. 2011) have been inspected to see which interpretation is correct. Those where the foetus was recorded as "lost" have been deleted from the database, while those where the foetus was recorded as "early stage" have been retained. Whales for which an original "passport" could not be located were also deleted, making a total of 59 records omitted from the analysis. The resultant total of pregnant females used in the database for this expedition was therefore 2070 (Table 1).

For the remaining two Soviet factory ships, the Sovetskaya Ukraina and Slava, data for 1448 pregnant females were available from the International Whaling Commission (IWC) database. From these, all records where the

Table 1: Number of pregnant sperm whales reported by Soviet expeditions to the Southern Hemisphere (after adjustment for probable errors).

\begin{tabular}{lrrrr}
\hline & Slava & Yuriy Dolgorukiy & Sovetskaya Ukraina & Total \\
\hline $1961 / 62$ & 10 & 82 & 32 & 109 \\
$1962 / 63$ & 36 & 70 & 62 & 388 \\
$1963 / 64$ & 118 & 208 & 194 & 839 \\
$1964 / 65$ & 164 & 481 & 44 & 113 \\
$1965 / 66$ & 69 & & 48 & 113 \\
$1966 / 67$ & & 65 & 149 & 162 \\
$1967 / 68$ & & 13 & 87 & 111 \\
$1968 / 69$ & & 24 & 153 & 153 \\
$1969 / 70$ & & 49 & 99 & 148 \\
$1970 / 71$ & & 328 & & 328 \\
$1971 / 72$ & & 255 & & 255 \\
$1972 / 73$ & & 197 & & 197 \\
$1973 / 74$ & & 298 & 298 & 3306 \\
$1974 / 75$ & & 2070 & & \\
Total & 397 & & &
\end{tabular}


foetal length was given as 0 or 1 were omitted, being considered as unhelpful or ambiguous, respectively (no "passports" were available to establish whether the latter foetuses were "lost" or "in early stage"). The resultant total of pregnant females available from these two expeditions was therefore 1236 (Table 1 ).

Catches were made between October and the following May, but over 95\% occurred in the 6 months November to April, or from late spring through summer to mid autumn. Two peaks [in November/December (32.8\%) and March/April (55.2\%)] presumably corresponded to the movements of the expeditions entering and leaving the Antarctic, respectively.

Pregnant females were taken between $23^{\circ} \mathrm{N}$ and $56^{\circ} \mathrm{S}$ (Table 2); no catches were taken between $100^{\circ}$ and $175^{\circ} \mathrm{W}$, so there are no data for the Central Pacific Ocean. In addition, latitudinal coverage was fair in the Atlantic and Indian Oceans, but restricted to higher latitudes in the Southwest Pacific and lower latitudes in the Southeast Pacific.

After omitting four records as their inclusion constituted levels of the "Latitude" factor with too few records, the remaining 3302 data records (including those north of the equator) for the lengths of pregnant females were used in this analysis. All animals were measured to the nearest $\mathrm{cm}$. The model fitted is given by:

$$
\text { Adult }_{\text {length }}=\mu+\beta_{\text {Basin }}+\gamma_{\text {Latitude }}+\omega_{\text {BasinxLatitude }}+\varepsilon
$$

where

Adult $_{\text {length }}$
$\mu$
Basin

is the length of an adult female sperm whale (in $0.1 \mathrm{~m}$ ), is the intercept, is a factor with 3 levels associated with Atlantic $\left(60^{\circ} \mathrm{W}-20^{\circ} \mathrm{E}\right)$, Indian $\left(20^{\circ}-140^{\circ} \mathrm{E}\right)$ and Pacific Ocean $\left(140^{\circ} \mathrm{E}-175^{\circ} \mathrm{W}, 100^{\circ}-60^{\circ} \mathrm{W}\right)$ basins,
Latitude

is a factor with 14 levels associated with 5-degree blocks of latitude values spanning $50^{\circ} \mathrm{S}-29^{\circ} \mathrm{N}$ (excluding $15^{\circ}-20^{\circ} \mathrm{N}$ ),

Basin $\times$ Latitude is the interaction between Basin and Latitude, and

$\varepsilon \quad$ is the error term assumed to be normally distributed.

Variants of this model were considered as well as one which included a factor "Expedition" with three levels associated with identity of expedition. The model in equation (1) was selected over other variants on the basis of its Akaike's information criterion (AIC) value.

\section{Results}

To determine the importance of each of the explanatory variables in the model, each individual variable was fitted to the adult female lengths of the sperm whales, as well as combinations of the explanatory variables. The AIC value as well as the percentage of the total variation of adult female lengths for each model fitted are shown in Table 3. The inclusion of the explanatory variable representing the expedition $\left(\xi_{\text {Expedition }}\right)$ alone had the highest AIC value and lowest $r_{\text {adj }}^{2}$ statistic. The $r_{\text {adj }}^{2}$ statistic did not change and the AIC value increased when omitting this explanatory variable from the model with all the other explanatory variables (Table 3), so that it was excluded from further analyses that included interaction terms. Table 4 shows model predicted adult lengths of pregnant sperm whales for each level of latitude and ocean basin for the final general linear model (GLM) of equation (1) which was selected on the basis of AIC.

Table 2: Distribution of pregnant sperm whales taken by Soviet whalers by latitude and ocean basin, 1961/1962-1974/1975.

\begin{tabular}{|c|c|c|c|c|c|}
\hline \multirow[t]{2}{*}{ Latitude } & \multirow{2}{*}{$\begin{array}{r}\text { Atlantic Ocean } \\
60^{\circ} \mathrm{W}-20^{\circ} \mathrm{E}\end{array}$} & \multirow{2}{*}{$\begin{array}{r}\text { Indian Ocean } \\
20^{\circ}-140^{\circ} \mathrm{E}\end{array}$} & \multicolumn{2}{|r|}{ Pacific Ocean } & \multirow[t]{2}{*}{ Tota } \\
\hline & & & $140^{\circ} \mathrm{E}-175^{\circ} \mathrm{W}$ & $100^{\circ}-60^{\circ} \mathrm{W}$ & \\
\hline $20-30^{\circ} \mathrm{N}$ & 40 & & & & 40 \\
\hline $10-20^{\circ} \mathrm{N}$ & & 31 & & & 31 \\
\hline $0-10^{\circ} \mathrm{N}$ & 6 & 50 & & & 56 \\
\hline $0-10^{\circ} \mathrm{S}$ & 13 & 26 & & 7 & 46 \\
\hline $10-20^{\circ} \mathrm{S}$ & 15 & 9 & & 35 & 59 \\
\hline $20-30^{\circ} \mathrm{S}$ & 178 & 102 & & 9 & 289 \\
\hline $30-40^{\circ} \mathrm{S}$ & 999 & 1106 & 83 & & 2188 \\
\hline $40-50^{\circ} \mathrm{S}$ & 264 & 28 & 302 & & 594 \\
\hline $50-60^{\circ} \mathrm{S}$ & & 3 & & & 3 \\
\hline Total & 1515 & 1355 & 385 & 51 & 3306 \\
\hline
\end{tabular}


Table 3: The Akiake's information criterion (AIC) and the percentage of the total variation of adult female lengths of sperm whales explained by various general linear models (GLMs).

\begin{tabular}{|c|c|c|c|c|}
\hline Model & AIC & $\triangle \mathrm{AIC}$ & $\% r_{\text {adj }}^{2}$ & $\Delta \% r_{\text {adj }}^{2}$ \\
\hline Adult $_{\text {length }}=\mu+\beta_{\text {Basin }}+\varepsilon$ & 39,819 & 304 & 7.7 & 8.9 \\
\hline Adult $_{\text {length }}=\mu+\gamma_{\text {Latitude }}+\varepsilon$ & 39,728 & 213 & 10.5 & 6.1 \\
\hline Adult $_{\text {length }}=\mu+\xi_{\text {Expedition }}+\varepsilon$ & 40,058 & 543 & 0.8 & 15.8 \\
\hline Adult $_{\text {length }}=\mu+\beta_{\text {Basin }}+\gamma_{\text {Latitude }}+\varepsilon$ & 39,545 & 30 & 15.4 & 1.2 \\
\hline Adult $_{\text {length }}=\mu+\beta_{\text {Basin }}+\xi_{\text {Expedition }}+\varepsilon$ & 39,812 & 297 & 8.0 & 8.6 \\
\hline Adult $_{\text {length }}=\mu+\gamma_{\text {Latitude }}+\xi_{\text {Expedition }}+\varepsilon$ & 39,701 & 186 & 11.3 & 5.3 \\
\hline Adult $_{\text {length }}=\mu+\beta_{\text {Basin }}+\gamma_{\text {Latitude }}+\xi_{\text {Expedition }}+\varepsilon$ & 39,546 & 31 & 15.4 & 1.2 \\
\hline Adult $_{\text {length }}=\mu+\beta_{\text {Basin }}+\gamma_{\text {Latitude }}+\omega_{\text {Basinxlatitude }}+\varepsilon$ & 39,515 & 0 & 16.6 & 0 \\
\hline
\end{tabular}

$\Delta \% r_{\text {adj }}^{2}$ is the decrease in $\% r_{\text {adj }}^{2}$ compared to the "best" model and $\Delta \mathrm{AIC}$ is the increase in AIC compared to the "best" model.

Table 4: Model predicted lengths $(\times 10 \mathrm{~cm})$ of adult female sperm whales, with their standard errors in percentiles, for each level of latitude and ocean basin as obtained from the GLM analyses.

\begin{tabular}{lrrr}
\hline Latitude & \multicolumn{3}{c}{ Ocean Basin } \\
\cline { 2 - 4 } & Atlantic & Indian & Pacific \\
\hline $20^{\circ} \mathrm{N}-25^{\circ} \mathrm{N}$ & $97.70(1.09)$ & & \\
$10^{\circ} \mathrm{N}-15^{\circ} \mathrm{N}$ & $94.88(1.31)$ & & \\
$5^{\circ} \mathrm{N}-10^{\circ} \mathrm{N}$ & $97.00(3.44)$ & $90.21(1.40)$ & \\
$0^{\circ} \mathrm{N}-5^{\circ} \mathrm{N}$ & $102.00(4.86)$ & $94.46(1.35)$ & \\
$5^{\circ} \mathrm{S}-0^{\circ} \mathrm{S}$ & $100.20(3.07)$ & $96.54(1.40)$ & \\
$10^{\circ} \mathrm{S}-5^{\circ} \mathrm{S}$ & $103.50(2.43)$ & $99.00(3.97)$ & $95.44(2.29)$ \\
$15^{\circ} \mathrm{S}-10^{\circ} \mathrm{S}$ & $96.00(4.86)$ & $97.37(2.43)$ & $93.76(1.67)$ \\
$20^{\circ} \mathrm{S}-15^{\circ} \mathrm{S}$ & $101.15(1.91)$ & & $93.94(1.72)$ \\
$25^{\circ} \mathrm{S}-20^{\circ} \mathrm{S}$ & $99.32(0.77)$ & $98.08(1.98)$ & $96.44(2.29)$ \\
$30^{\circ} \mathrm{S}-25^{\circ} \mathrm{S}$ & $99.98(0.69)$ & $97.93(0.72)$ & \\
$35^{\circ} \mathrm{S}-30^{\circ} \mathrm{S}$ & $103.36(0.27)$ & $99.08(0.26)$ & $108.79(1.20)$ \\
$40^{\circ} \mathrm{S}-35^{\circ} \mathrm{S}$ & $103.87(0.36)$ & $100.78(0.35)$ & $103.82(0.97)$ \\
$45^{\circ} \mathrm{S}-40^{\circ} \mathrm{S}$ & $105.92(0.43)$ & $100.83(1.40)$ & $104.08(0.41)$ \\
$50^{\circ} \mathrm{S}-45^{\circ} \mathrm{S}$ & $105.50(1.98)$ & $110.25(3.44)$ & $108.47(1.77)$ \\
\hline
\end{tabular}

Figure 1 shows the raw data for the length of pregnant sperm whales by latitude. Figure 2 shows the model predicted adult length of pregnant sperm whales. As the GLM selected includes an interaction term between latitude and ocean basin, these model predictions are shown for each level of the latitude factor and each level of the ocean basin factor. Figure 3 shows these predicted lengths for each basin in the same plot for ease of comparison. A decline in these lengths from south to north as latitude changes is evident in all ocean basins, more so in the Indian Ocean (with a decrease of about $200 \mathrm{~cm}$ ) and more gradually in the Atlantic Ocean (about $80 \mathrm{~cm}$ ). Data for the Pacific Ocean are more sparse and no information is available there north of the equator, but again the mean length drops by about $100 \mathrm{~cm}$ between females south of $30^{\circ} \mathrm{S}$ and those north of $25^{\circ} \mathrm{S}$, although the samples originate from the western South Pacific and eastern South Pacific Ocean, respectively.

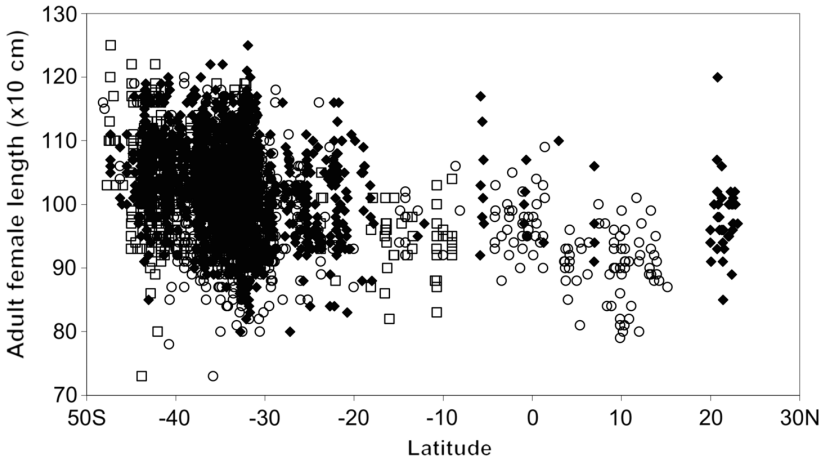

Figure 1: Variation in length of pregnant sperm whales with latitude in Soviet catches, 1961/1962-1974/1975 squares, Pacific Ocean; diamonds, Atlantic Ocean; circles, Indian Ocean.

\section{Discussion}

Although latitudinal coverage was uneven, and overall coverage in the South Pacific was poor, the analysis in this article clearly indicates that the body size of mature (pregnant) female sperm whales taken in Soviet pelagic whaling in the Southern Hemisphere varied with latitude, with individuals taken in tropical waters being significantly smaller than those in temperate regions.

Although the expedition effect was shown to be minor, the question still needs to be asked whether these features in the observations could represent an industryrelated artefact. There would not seem to be any obvious operational reason why the observations should represent deliberately falsified whaling data. Although the Soviet whaling operations themselves involved serious misreporting and/or falsification of records submitted to the Bureau of International Whaling Statistics (Ivashchenko et al. 2011), the statistics used here were not intended for international perusal. In addition, the taking of pregnant females was not illegal, and there is no sign from the size composition of the animals taken that there was any 

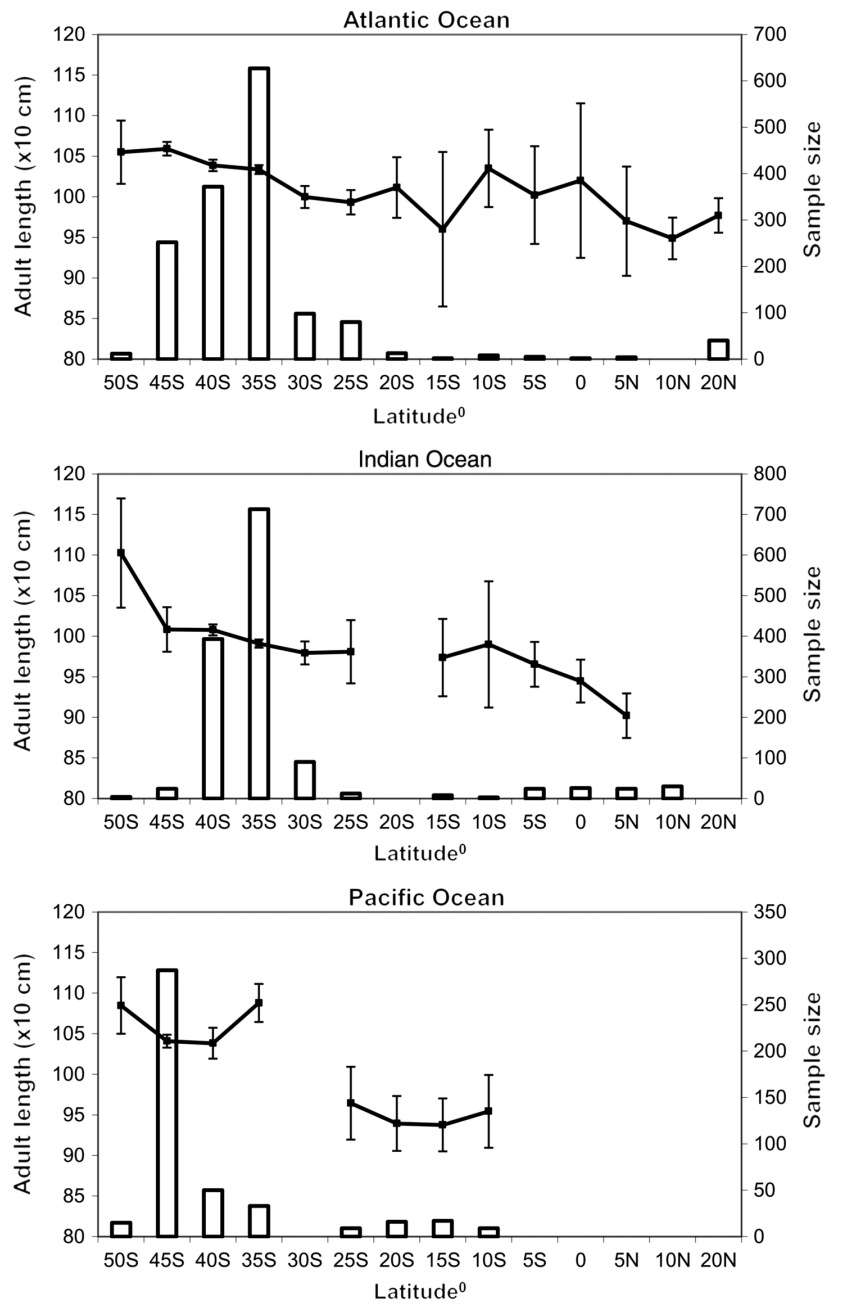

Figure 2: Model predicted adult length of pregnant sperm whales (with 95\% confidence intervals) for each level of latitude and ocean basin. The histograms indicate sample size.

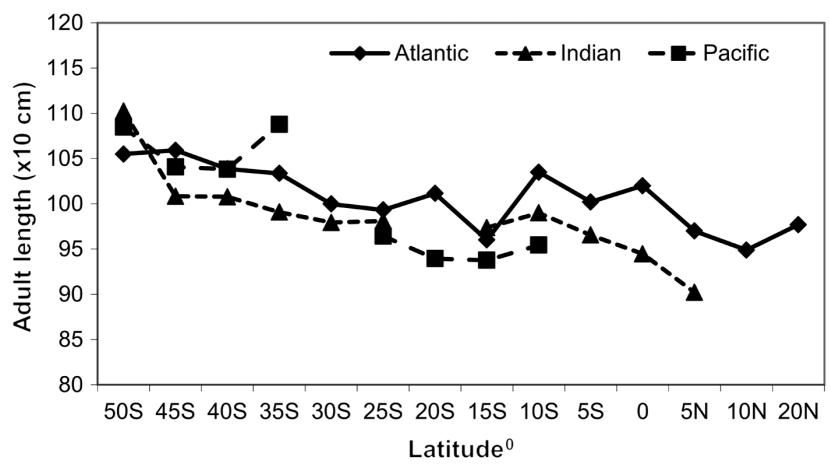

Figure 3: Comparison of model predicted length of pregnant sperm whales for each level of latitude and by ocean basin.

manipulation of recorded lengths to meet the minimum length requirement, which at that stage was $38 \mathrm{ft}(11.6 \mathrm{~m})$ for pelagic whaling. Selection was also unlikely to have been a factor, as apart from the non-selective nature of the Soviet operations, such selection would presumably have been for larger animals irrespective of locality.

Furthermore, there is independent evidence of the diminutive nature of female sperm whales in some low latitude areas. In the northern Indian Ocean, photogrammetric measurements of 49 sperm whales (females and immature males) off the east coast of Sri Lanka in 1983 and 1984 produced lengths ranging from 7 to $11 \mathrm{~m}$ with a mode at 9-9.5 m; 87.7\% were $<10 \mathrm{~m}$ long (Gordon 1990). In the tropical eastern Pacific, Waters and Whitehead (1990) made similar measurements of at least 200 different sperm whales off the Galapagos Islands in 1985 and 1987; these were also believed to be females and small males. They concluded that females appeared to be smaller (by some $0.8 \mathrm{~m}$ ) at every age when compared with other sperm whale populations (Ohsumi 1971, Gambell 1972). A nearly identical size distribution (8-11 $\mathrm{m}$ ) was found for 79 females and immature sperm whales measured photogrammetrically off the Seychelles in 1990 (Kahn et al. 1993).

Some 19th-century whalers also believed that female sperm whales differed in size in different areas. According to Captain HW Seabury (Clark 1887): "they vary much in size in different places. In the Caribbean Sea, Gulf of Mexico, and along the Gulf Stream through the Atlantic, they run small, and full-grown cows will not average over 15 barrels”. Seabury's observations for the Gulf of Mexico are confirmed by a photogrammetric study in 2002/3, where $84.2 \%$ of 38 females and immatures measured were $7.5-10 \mathrm{~m}$ long, appreciably smaller than 167 females/ immatures measured earlier using the same technique in the Gulf of California, where 82\% were 9-11.5 m long. Furthermore, a first-year non-neonate in the Gulf of Mexico measured only $3.3 \mathrm{~m}$, substantially below the expected size at birth (Jaquet 2006). Sperm whales around the Ladrone (Mariana) Islands, in the Sulu Sea, Mindora Strait and around the East Indian islands were also said to be generally very small, and mostly cows with calves (Clark 1887), and whales in Indonesian waters were considered to be particularly small (D. Chatwin, pers. comm.). Nine whales landed by whalers from Lamalera, Indonesia, in 1979 ranged from 6.12 to $10.1 \mathrm{~m}$, with five females between 8.5 and $10 \mathrm{~m}$ averaging $9.3 \mathrm{~m}$ in length (Hembree 1980). The smaller size of Indian Ocean females was also commented upon by Seabury: "Those caught in the Pacific Ocean near the equator as far as longitude $135^{\circ} \mathrm{W}$, average about 25 barrels while those caught farther west and in most parts of the Indian Ocean run smaller" (Clark 1887). Wray and Martin (1983) commented on the belief that sperm whales in the Indian Ocean were undersized, and showed the oil 
yields of 222 whales, of which 107 had yields of 20 barrels or less. Unfortunately the use of oil yield data to demonstrate size differences assumes that there is no regional variation in fatness; however, in a study of sperm whales in the southeast Pacific between latitudes $5^{\circ}$ and $36^{\circ} 40^{\prime} \mathrm{S}$, several indicators of fatness suggested a decreasing tendency from south to north (Clarke et al. 1988).

Latitudinal segregation of sperm whale stocks has been proposed for the western North Pacific by Kasuya and Miyashita (1988), with one female concentration inhabiting the western North Pacific Gyre, to the north of the Oyashio Front, and a second to the south of the front of the Kuroshio current system; the former summers mainly north of $40^{\circ} \mathrm{N}$ and the latter south of $30^{\circ} \mathrm{N}$. This proposal has been criticized by Mizroch and Rice (2013), principally on the grounds that there was overlap between the stock boundaries and a number of Discovery mark recoveries showed movement across them (although these issues were considered by Kasuya and Miyashita). Nevertheless, Amano et al. (2014) have shown further latitudinal differentiation within the western North Pacific, with females and immature sperm whales off Japan (at about $34^{\circ} \mathrm{N}$ ) differing in vocal repertoire and diving behaviour from those off the Ogasawara Islands (at about $27^{\circ} \mathrm{N}$ ).

A latitudinal zonation of sperm whale stocks was suggested by Wilkes (Clark 1887). He proposed four zones, two from the equator to the Tropics of Capricorn and Cancer (ca $23^{\circ} 30^{\prime} \mathrm{S}$ and $\mathrm{N}$, respectively), and two from those tropics to $50^{\circ} \mathrm{S}$ and $\mathrm{N}$, respectively. Although these zones were created ostensibly for convenience of description, in his subsequent elaboration Wilkes seems to make a distinction between the behaviour of sperm whales in the tropics (where they were "almost always to be met with") and at higher latitudes, where he describes several patterns in seasonality and movement. Rice (1977) concluded that because 19th century whalers took sperm whales near the equator all across the Pacific year round, it was possible that they were a separate breeding stock, although they could also have represented individuals from both northern and southern hemispheres on their respective winter migrations 6 months apart. A year-round presence in equatorial regions has subsequently been confirmed in an analysis including information about where whales were both seen and not seen by 19th century whalers (Smith et al. 2012). The possible non-migratory nature of the equatorial whales has also received some support from observations that females from the Galápagos population are non-migratory, whereas females in higher latitudes, such as off Durban (at $30^{\circ} \mathrm{S}$ ), seem to show clear seasonal migrations (Whitehead and Weilgart 2000).
Other, indirect evidence suggests that there may be latitudinal differentiation of sperm whale populations. Kasuya and Miyashita (1988) refer to reported differences in colour, incidence of oval (Isistius) scarring, tooth size, shape of lower jaw and even schooling behaviour between southern and northern sperm whales in the western North Pacific. Mikhalev (2000) reports that sperm whales from the Arabian Sea have a substantially higher incidence of ambergris than whales from higher latitudes, and lack fresh Isistius bites. The prevalence of ambergris in the population is suggested by the importance attached to its collection from the beach in Oman, South Yemen (Gallagher 1991) and Somalia (Small and Small 1991). Nineteenth-century whalers also remarked on the greater yield of spermaceti (said normally to be about one-sixth of the total yield) from whales taken in the vicinity of the equator than from those off Japan or in the North Pacific (Bennett 1840). Differences have also been found in social structure between female sperm whales from the eastern Pacific and North Atlantic Oceans (Whitehead et al. 2012). Jaquet (2006) reports that the Gulf of Mexico whales, besides being smaller, have a different social organization, smaller group sizes and a higher incidence of some scarring types (mostly holes in and missing portions of flukes) than Gulf of California whales, while both Hembree (1980) and Fuchs (1978) refer to the small group sizes, put at three to five individuals by Fuchs (1978), of Indonesian sperm whales.

\section{Conclusions}

Analysis of pregnant sperm whales in the catches of Soviet whaling expeditions en route to and from the Antarctic indicates that the length of mature females tends to decline from south to north, a finding that seem to be confirmed by a number of independent lines of evidence, at least in as far as some tropical populations appear to be smaller than average. The mechanism(s) that could give rise to such a size differentiation are unclear - they could be behavioural, genetic or environmental.

An ontogenetic explanation, that there could be partitioning of the adult female population by size, with larger individuals migrating into higher latitudes - as occurs in males (Best 1979) - would seem to be contradicted by the nature of female sperm whale society, where social units consist of whales of different sizes/ages that live and move together over periods of years (Whitehead 2003), although admittedly the longer term dynamics of these units have hardly been studied. As discussed earlier, evidence of genetic differentiation of female populations is sparse, 
although at least one of the regions with small females (Gulf of Mexico) has been shown to be genetically distinct from other populations in the North Atlantic using mtDNA (Engelhaupt et al. 2009). However there has been no intensive sampling of female sperm whales in the Southern Hemisphere over the range of latitudes covered by the data in this article, so whether there is a genetic basis for the size differences must remain an open question.

Differences in apparent foraging behaviour between sympatric clans of female and immature sperm whales have been described for the North Pacific and South Pacific, manifested as different movement patterns, defecation rates and diving synchronies (Whitehead and Rendell 2004), or differences in the diurnal pattern of diving behaviour (Aoki et al. 2007). If these are a response to differing prey availabilities, and are culturally transmitted, they could form the basis for differences in energetic budgets between clans, and hence a mechanism whereby some populations may exhibit different growth patterns to others. It may also be that different clans have differing prey preferences or that different clans occupy different geographical regions. There is however little information on the distribution and abundance of squids and no information on clan composition in the Southern Atlantic or Indian Oceans so that such mechanisms are not readily identifiable.

Although the lack of data on abundance for oceanic squids that are the prey of sperm whales prevents any real test of McNab's resource rule, there are indications of declines in the size of individual teuthids (albeit neritic and shelf-edge species) from high to low latitudes (Pauly 1998, Rosa et al. 2012), and some data on declining blubber thickness in female sperm whales from high to low latitudes (Clarke et al. 1988). Taken together, these would seem to make the concept of reduced availability of resources (also in terms of the availability and size of prey) at low latitudes a real possibility to explain the trends found in mean sizes of adult female sperm whales.

Acknowledgments: We are extremely grateful to C. Allison of the IWC Secretariat for her extraction of data. This analysis is based upon work supported by the National Research Foundation, South Africa, under grant numbers 2047517 and 2053574. Assistance provided by D.S. Butterworth and Ken Findlay is greatly appreciated.

\section{References}

Amano, M., A. Kourogi, K. Aoki, M. Yoshioka and K. Mori. 2014. Differences in sperm whale codas between two waters off Japan: possible geographic separation of vocal clans. J. Mammal. 95: 169-175.

Anonymous 1995. Soviet Antarctic whaling data (1947 - 1972). Centre for Russian Environmental Policy, Moscow.

Aoki, K., M. Amano, M. Yoshioka, K. Mori, D. Tokuda and N. Miyazaki. 2007. Diel diving behavior of sperm whales off Japan. Mar. Ecol. Prog. Ser. 349: 277-287.

Bennett, F.D. 1840. Narrative of a whaling voyage round the globe from the year 1833-1836. London, Richard Bentley. 2 vols.

Best, P.B. 1979. Social organization in sperm whales, Physeter macrocephalus. In: (H.E. Winn and B.L. Olla, eds.) Behavior of marine animals. Current perspectives in research 3. Cetaceans. Plenum Press, New York-London. pp. 227-289.

Bond, J.M. 1999. Genetic analysis of the sperm whale (Physeter macrocephalus) using microsatellites. PhD thesis, University of Cambridge, Cambridge, UK.

Clark, A.H. 1887. History and present condition of the fishery. In: (G.B. Goode, ed.) The fisheries and fishery industries of the United States. Section V. History and methods of the fisheries. Vol II. US Commission of Fish and Fisheries, Washington. pp. 3-218.

Clarke, R., O. Paliza and A. Aguayo L. 1988. Sperm whales of the southeast Pacific. Part IV: Fatness, food and feeding. Investig. Cetacea 21: 53-195.

Engelhaupt, D., A.R. Hoelzel, C. Nicholson, A. Frantzis, S. Mesnick, S. Gero, H. Whitehead, L. Rendell, P. Miller, R. de Stefanis, A. Cañadas, S. Airoldi and A.A. Mignucci-Giannoni. 2009. Female philopatry in coastal basins and male dispersion across the North Atlantic in a highly mobile marine species, the sperm whale (Physeter macrocephalus). Mol. Ecol. 18: 4193-4205.

Fuchs, B. 1978. Report on a two week survey of the whaling industry in Lamalera, Nusa Tangarra. World Wildl. Fund Rep. 1513: 1-7.

Gallagher, M.D. 1991. Strandings of sperm whales (Physeter macrocephalus) on the shores of Oman, Eastern Arabia. UNEP Mar. Mamm. Tech. Rep. 3: 241-245.

Gambell, R. 1972. Sperm whales off Durban. Discovery Rep. 35:199-358.

Golovlev, F. 2000. The echo of mystery of whales. In: (A.V. Yablokov, V.A. Zemsky, eds.) Soviet whaling data (1949-1979). Centre for Russian Environmental Policy, Moscow. pp. 11-24.

Gordon, J. 1990. A simple photographic technique for measuring the length of whales from boats at sea. Rep. int Whal. Comm. 40: 581-588.

Hembree, D. 1980. Biological aspects of the cetacean fishery at Lamalera, Lembata. Report on World Wildl. Fund Proj. 1428: 1-55, 2 app.

Ivashchenko, Y.V., P.J. Clapham and R.L. Brownell Jr. 2011. Soviet illegal whaling: the devil and the details. Mar. Fish. Rev. 73: 1-19.

Ivashchenko, Y.V., R.L. Brownell Jr and P.J. Clapham. 2014. Distribution of Soviet catches of sperm whales Physeter macrocephalus in the North Pacific. Endang. Species Res. 25: 249-263.

Ivashin, M.V. 1967. [Whale globe-trotter]. Prir. 8: 105-107.

Jaquet, N. 2006. A simple photogrammetric technique to measure sperm whales at sea. Mar Mamm. Sci. 22: 862-879.

Kahn, B., H. Whitehead and M. Dillon. 1993. Indications of densitydependent effects from comparisons of sperm whale populations. Mar. Ecol. Progr. Ser. 93: 1-7.

Kasuya, T. and T. Miyashita. 1988. Distribution of sperm whale stocks in the North Pacific. Sci. Rep. Whales Res. Inst. Tokyo 39: 31-75. 
Lyrholm, T. and U. Gyllensten. 1998. Global matrilineal population structure in sperm whales as indicated by mitochondrial DNA sequences. Proc. R. Soc. Lond. B 265: 1679-1684.

Lyrholm, T., O. Leimar, B. Johanneson and U. Gyllensten. 1999. Sexbiased dispersal in sperm whales: contrasting mitochondrial and nuclear genetic structure of global populations. Proc. $R$. Soc. Lond. B 266: 347-354.

McNab, B.K. 2010. Geographic and temporal correlations of mammalian size reconsidered: a resource rule. Oecologia 164: 13-23.

Mesnick, S.L., B.L. Taylor, F.I. Archer, K.K. Martien, S.E. Treviño, B.L. Hancock-Hanser, S.C.M. Medina, V.L. Pease, K.M. Robertson, J.M. Straley, R.W. Baird, J. Calambokidis, G.S. Schorr, P. Wade, V. Burkanov, C.R. Lunsford, L. Rendell and P.A. Morin. 2011. Sperm whale population structure in the eastern and central North Pacific inferred by the use of singlenucleotide polymorphisms, microsatellites and mitochondrial DNA. Mol. Ecol. Resources 11 (Suppl. 1): 278-298.

Mikhalev, Y.A. 2000. Whaling in the Arabian Sea by the whaling fleets Slava and Sovetskaya Ukraina. In: (A.V. Yablokov and V.A. Zemsky, eds.) Soviet whaling data (1949-1979). Centre for Russian Environmental Policy, Moscow. pp. 141-181.

Mizroch, S.A., and D.W. Rice. 2013. Ocean nomads: distribution and movements of sperm whales in the North Pacific shown by whaling data and Discovery marks. Mar. Mamm. Sci. 29: E136-E165.

Ohsumi, S. 1971. Some investigations on the school structure of sperm whale. Sci. Rep. Whales Res. Inst., Tokuo 23: 1-25.

Pauly, D. 1998. Why squid, though not fish, may be better understood by pretending they are. S. Afr. J. mar. Sci. 20: 47-58.

Rendell, L.E., and H. Whitehead. 2003. Vocal clans in sperm whales (Physeter macrocephalus). Proc. R. Soc. Lond. B 270: 225-231.

Rendell, L., S.L. Mesnick, M.L. Dalebout, J. Burtenshaw and H.Whitehead. 2012. Can genetic differences explain vocal dialect variation in sperm whales, Physeter macrocephalus? Behav. Genet. 42: 332-343.
Rice, D.W. 1977. Sperm whales in the equatorial Eastern Pacific: population size and social organization. Rep. int. Whal. Comm. 27: 333-336.

Rice, D.W. 1989. Marine mammals of the world. Systematics and distribution. Soc. Mar. Mammal. Spec. Publ. 4: 231.

Rosa, R., L. Gonzalez, H.M. Dierssen and B.A. Seibel. 2012. Environmental determinants of latitudinal size-trends in cephalopods. Mar Ecol. Progr. Ser. 464: 153-165.

Small, J.A., and G.J. Small. 1991. Cetacean observations from the Somali Democratic Republic, September 1985 through May 1987. UNEP Mar. Mamm. Tech. Rep. 3: 179-210.

Smith, T.D., R.R. Reeves, E.A. Josephson and J.N. Lund. 2012. Spatial and seasonal distribution of American whaling and whales in the age of sail. PLoS One 7: 1-25.

Waters, S. and H. Whitehead. 1990. Population and growth parameters of Galapagos sperm whales estimated from length distributions. Rep. int. Whal. Comm. 40: 225-235.

Whitehead, H. 2003. Sperm whales. Social evolution in the ocean. University of Chicago Press, Chicago and London.

Whitehead, H. and L. Rendell. 2004. Movements, habitat use and feeding success of cultural clans of South Pacific sperm whales. J. Anim. Ecol. 73: 190-196.

Whitehead, H., and L. Weilgart. 2000. The sperm whale. Social females and roving males. In: (J. Mann, R.C. Connor, P.L. Tyack and H. Whitehead, eds.) Cetacean Societies. Field Studies of Dolphins and Whales. University of Chicago Press, Chicago and London. pp. 154-172.

Whitehead, H., R. Antunes, S. Gero, S.N.P. Wong, D. Engelhaupt and L. Rendell. 2012. Multilevel societies of female sperm whales (Physeter macrocephalus) in the Atlantic and Pacific: why are they so different? Int. J. Primatol 33: 1142-1164.

Wray, P. and K.R. Martin. 1983. Historical whaling records from the Western Indian Ocean. Rep. int. Whal. Comm. (Spec. Issue 5): 213-241.

Yablokov, A.V. and V.A. Zemsky. 2000. Soviet whaling data (19491979). Centre for Russian Environmental Policy, Moscow. 